\title{
High Level Cycling Performance 10 Years after Cardiac Trans- plantation
}

\section{Grazzi Giovanni ${ }^{1}$, Totti Valentina ${ }^{2}$, Myers Jonathan ${ }^{3}$, Mosconi Giovanni $^{4}$, Gambaretto Camilla ${ }^{4}$, Sambri Vittorio ${ }^{5}$, Trerotola Manuela ${ }^{6}$, Nanni Costa Alessandro ${ }^{6 *}$ and Sella Gianluigi ${ }^{7}$}

${ }^{1}$ Center of Biomedical Studies Applied to Sport, University of Ferrara, Italy

${ }^{2}$ Department of Biomedical and Neuromotor Sciences, University of Bologna, Italy

${ }^{3}$ Veterans Affairs Palo Alto Health Care System, Stanford University School of Medicine, USA

${ }^{4}$ Unit of Nephrology, Morgagni-Pierantoni Hospital, Italy

${ }^{5}$ The Greater Romagna Hub Laboratory, AUSL of Romagna, Italy

${ }^{6}$ Italian National Transplant Centre, Higher Institute of Health, Italy

${ }^{7}$ Ravenna Sports Medicine Center - AUSL Romagna, Italy

*Corresponding author: Alessandro Nanni Costa, Italian National Transplant Centre, Higher Institute of Health, Viale Regina Elena 299, 00161 Roma, Italy, Tel: +39-06-49904040, Fax: +39-0649904101

\begin{abstract}
Purpose: To describe cycling performance in a well-trained male a decade after Cardiac Transplantation (CTX).

Case report: The patient was diagnosed with arrhythmogenic right ventricular cardiomyopathy at 14 years of age and underwent CTX at 35 years. Exercise training began 3 weeks after CTX, and progressively increased in volume and intensity. Ten years after CTX he participated in twelve one-day cycling races over an eight-month period. Maximal cardiopulmonary exercise test was performed before the study. One race was monitored using a power meter.
\end{abstract}

Results: $\mathrm{VO}_{2}$ peak $(47.2 \mathrm{~mL} / \mathrm{kg} / \mathrm{min})$, maximal HR (161 $\mathrm{bpm})$, and oxygen pulse (18.8 $\mathrm{mL} / \mathrm{bpm})$ were $113 \%, 92 \%$, and $118 \%$ of age-predicted values respectively. $\mathrm{HR}, \mathrm{W}$, and relative $\mathrm{VO}_{2}$ at the ventilatory threshold and at the respiratory compensation point were $128 \mathrm{bpm}, 120 \mathrm{~W}$, and $75 \%$ $\mathrm{VO}_{2}$ peak, and $142 \mathrm{bpm}, 155 \mathrm{~W}$, and $86 \% \mathrm{VO}_{2}$ peak respectively. Cycling economy was $\sim 80 \mathrm{~W}$ per liters per $\mathrm{O}_{2} / \mathrm{min}$. The race was completed in 7 hours and 56 minutes, at an average of $141 \mathrm{bpm}$ and $162 \mathrm{~W}$, remaining between moderate-to-high intensity (4 h $2 \mathrm{~min}$ ), and above high-to-severe intensity (2 h 19 min).

Conclusion: Long-term aerobic training may result in a remarkable cycling performance a decade after CTX, likely because of cardiovascular adaptations.

\section{Keywords}

Aerobic capacity, Exercise training, Exercise tolerance, Heart transplant recipients, Cycling, Sport performance

\begin{abstract}
Abbreviations
ANED: Associazione Nazionale Emodializzati, Dialisi E Trapianto; ARVC: Arrhythmogenic Right Ventricular Cardiomyopathy; ATP: Adenosine Triphosphate; NT-pro-BNP: $\mathrm{N}$-Terminal prohormone of Brain Natriuretic Peptide; CTX: Cardiac Transplantation; ECG: Electrocardiography; HR: Heart Rate; HTR: Heart Transplant Recipients; ICD: Implantable Cardioverter Defibrillator; RCP: Respiratory Compensation Point; RPE: Rating Of Perceived Exertion; $\mathrm{VCO}_{2}$ : Carbon dioxide output; $\mathrm{VO}_{2}$ : Oxygen uptake; $\mathrm{VO}_{2}$ peak: Peak oxygen uptake; VT: Ventilatory Threshold; W: power output
\end{abstract}

\section{Introduction}

Cardiac Transplantation (CTX) is a treatment option for selected individuals with end-stage heart failure. However, long-term outcomes are limited by the development of cardiovascular complications, and coronary allograft artery disease is the main cause of death in Heart Transplant Recipients (HTR) five years after intervention [1,2]. Training programs among HTR are

Citation: Giovanni G, Valentina T, Jonathan M, Giovanni M, Camilla G, et al. (2018) High Level Cycling Performance 10 Years after Cardiac Transplantation. Int J Sports Exerc Med 4:102. doi.org/10.23937/24695718/1510102

Accepted: August 21, 2018; Published: August 23, 2018

Copyright: (C) 2018 Giovanni G, et al. This is an open-access article distributed under the terms of the Creative Commons Attribution License, which permits unrestricted use, distribution, and reproduction in any medium, provided the original author and source are credited. 
recommended in the early post-operative period as well as in the long term [3] and cardiorespiratory fitness has been demonstrated to improve after exercise training $[4,5]$. Previous studies on the effects of exercise training in HTR have been performed early after CTX and have applied moderate exercise intensities $[6,7]$. The results of these studies are not entirely consistent, and how training late after CTX affects endurance capacity has not been well defined. Even less is known regarding the effects of strenuous and prolonged exercise training in long-term HTR.

Previous studies have analyzed performance by the assessment of physiological parameters such as peak oxygen uptake ( $\mathrm{VO}_{2}$ peak), which is generally considered the most important measure of cardiorespiratory fitness and endurance capacity. In cycling, analysis of power output in training and racing conditions has been shown to be a more valuable method for quantifying training intensity and cycling performance than $\mathrm{VO}_{2}$ peak [8]. In the current report, we describe laboratory and field data of a cyclist HTR who participated in 12 oneday cycling races over an eight-month period 10 years after CTX.

\section{Case Report: Materials and Methods}

The subject was enrolled with the support of ANED Sport (Associazione Nazionale Emodializzati, Dialisi e Trapianto), an association involved in promoting physical activity after solid organ transplantation. The study was approved by the institutional review board at the CEAV Romagna (Health Service of the Emilia-Romagna region, protocol number 2194/2011/I.5/481), and the subject gave written informed consent. The subject is a 45-yr-old-male, affected by Arrhythmogenic Right Ventricular Cardiomyopathy (ARVC) diagnosed in 1984, characterized by recurrent episodes of ventricular tachycardia treated with amiodarone and an Implantable Cardioverter Defibrillator (ICD) over time. At 35 years, because of the rapid progression to heart failure with biventricular dysfunction, he was placed on a cardiac transplant waiting list, and underwent CTX in 2004, receiving a donor heart from a 16 -yr-old male (78-kg, 185-cm). The post-operative course was normal. The post-CTX period was uneventful, leading rapidly to a complete recovery. Regular follow-up assessments, including coronary angiograms and endo-myocardial biopsies were performed to ensure that there were no tissue rejection episodes. After one year of cardiac rehabilitation, he started gradually to train for cycling. After 2 years post-CTX he began cycling outdoors, 4-5 sessions/week of 3-4 hours duration $(10,000-12,000 \mathrm{~km} /$ year) using a heart rate monitor, training in the range of 125-135 beats per minute (bpm).

Between February and October 2015 he completed 12 long course competitive races for a total of 1594 racing $\mathrm{km}$ (mean 132), and 30642 altitude gain (mean 2533). Medications and dosage at the time of testing, training, and racing included Ciclosporine, $150 \mathrm{mg} /$ day; Prednisone $2.5 \mathrm{mg}$ every second day; Verapamil 240 mg/day; Indobufene 200 mg/day; Pravastatin 40 mg/ day; Lansoprazole $15 \mathrm{mg} /$ day. The medical therapy was unchanged from 2006. No significant side effects have been reported.

Before to start the study the participant underwent a maximal Cardiopulmonary Exercise Test (CPX) on a wind-load cycle ergometer equipped with an SRM Powermeter [9]. Bicycle gearing was individualized according to the functional capacity and habits of the subject $[10,11]$. Integrated 12 -lead electrocardiographic tracings were continuously monitored and recorded during the test. Gas-exchange measurements were performed using a metabolic cart (CPET, Cosmed, Rome, Italy). Calibration of the system was performed immediately before the test by using a 3-liter syringe to calibrate the turbine, and a two-point calibration of the gas analyzers was performed using gases of known oxygen, carbon dioxide and nitrogen concentrations. Oxygen uptake $\left(\mathrm{VO}_{2}\right)$ and carbon dioxide output $\left(\mathrm{VCO}_{2}\right)$ were acquired breath-by-breath, and subsequently averaged over 15 seconds.

According to current recommendations, three exercise intensity zones were defined considering the first Ventilatory Threshold (VT) using the V-slope method, and a second ventilatory threshold or Respiratory Compensation Point (RCP) determined by the inversion of the $\mathrm{VE} / \mathrm{VCO}_{2}$ ratio as the nadir of the $\mathrm{VE} / \mathrm{VCO}_{2}$ versus work rate relationship [12]. Heart Rate Deflection Point (HRDP) was also determined [10]. Exercise intensity was considered light to moderate (below VT), moderate to high (between VT and RCP), and high to severe (above $\mathrm{RCP})$. CPX test results are presented in Table 1.

Echocardiography, cardiac magnetic resonance, coronary angiography, $\mathrm{N}$-terminal prohormone of brain natriuretic peptide (NT-pro-BNP) and monthly 24-hour ECG Holter monitoring, with a typical long training session included, were analyzed.

The subject performed one of these competitions (Maratona dles Dolomites) with a mobile powermeter mounted on his bike (SRM Professional Training system, Schoberer Rad Messtechnik, Julich, Germany). In order to take into account the climatic conditions and the residual torque applied on the SRM system, the zero off set frequency procedure was performed by the cyclists before the race. Data were recorded every 1 second, and transferred after the race from the SRM powercontrol for analysis.

The Maratona dles Dolomites was completed in 7 hours and 56 minutes, with the individual finishing $2841^{\text {st }}$ of 4449 finishing competitors, and $662^{\text {nd }}$ of 1061 in the age-group category (45 to 49 years). The Heart Rate (HR) versus time and altitude relationships are presented in Figure 1. Lowest, mean, and highest HR values 
Table 1: Cardiopulmonary exercise test results.

\begin{tabular}{|c|c|c|c|c|c|c|}
\hline & Start $^{*}$ & VT & RCP & HRDP & Maximum & \\
\hline & & & & & Achieved & $\%$ PRED \\
\hline \multicolumn{7}{|l|}{ Power output } \\
\hline Exercise time (min:sec) & $0: 00$ & $7: 45$ & $14: 40$ & $15: 35$ & $18: 30$ & - \\
\hline Workload (W) & 80 & 120 & 155 & 160 & $259^{* *}$ & - \\
\hline Cadence (RPM) & 60 & 73 & 86 & 89 & $104^{* *}$ & - \\
\hline \multicolumn{7}{|l|}{ Metabolic } \\
\hline $\mathrm{VO}_{2}(\mathrm{~mL} / \mathrm{kg} / \mathrm{min})$ & 22.9 & 34.4 & 39.3 & 39.7 & 47.2 & 113 \\
\hline $\mathrm{VO}_{2}$ (METs) & 6.5 & 9.8 & 11.2 & 11.3 & 13.5 & 124 \\
\hline $\mathrm{VO}_{2}(\mathrm{~L} / \mathrm{min})$ & 1395 & 2.100 & 2.400 & 2.420 & 2.789 & 110 \\
\hline $\mathrm{VCO}_{2}(\mathrm{~L} / \mathrm{min})$ & 998 & 1.900 & 2.350 & 2.430 & 3.800 & - \\
\hline $\operatorname{RER}\left(\mathrm{VCO}_{2} / \mathrm{VO}_{2}\right)$ & 0.72 & 0.92 & 0.98 & 1.00 & 1.26 & - \\
\hline \multicolumn{7}{|l|}{ Cardiovascular } \\
\hline Heart rate (bpm) & 108 & 128 & 142 & 144 & 161 & 92 \\
\hline Heart rate recovery (bpm at $1 \mathrm{~min})$ & - & - & - & - & 138 & - \\
\hline Oxygen pulse $\left(\mathrm{VO}_{2} / \mathrm{HR}, \mathrm{mL} / \mathrm{bpm}\right)$ & 11.8 & 15.1 & 16.9 & 16.8 & 18.8 & 130 \\
\hline \multicolumn{7}{|l|}{ Ventilatory } \\
\hline VE $\left(L-\min ^{-1}\right)$ & 26 & 48 & 59 & 63 & 135 & 96 \\
\hline Respiratory rate (br/min) & 15 & 18 & 24 & 26 & 52 & 104 \\
\hline $\mathrm{VE} / \mathrm{VO}_{2}\left(\mathrm{~L}-\mathrm{min}^{-1} / \mathrm{L}-\mathrm{min}^{-1}\right)$ & 19 & 22 & 24 & 26 & 43 & - \\
\hline VE/VCO ${ }_{2}\left(\right.$ L-min $\left.^{-1} / \mathrm{L}^{-\mathrm{min}^{-1}}\right)$ & 26 & 23 & 25 & 25 & 33 & - \\
\hline VE/ $\mathrm{VCO}_{2}$ slope & - & 21 & 21 & 21 & 29 & - \\
\hline $\mathrm{PetCO}_{2}(\mathrm{mmHg})$ & 39 & 43 & 43 & 44 & 36 & - \\
\hline
\end{tabular}

"After warm-up. "*mean values of the last minute of the CPX.

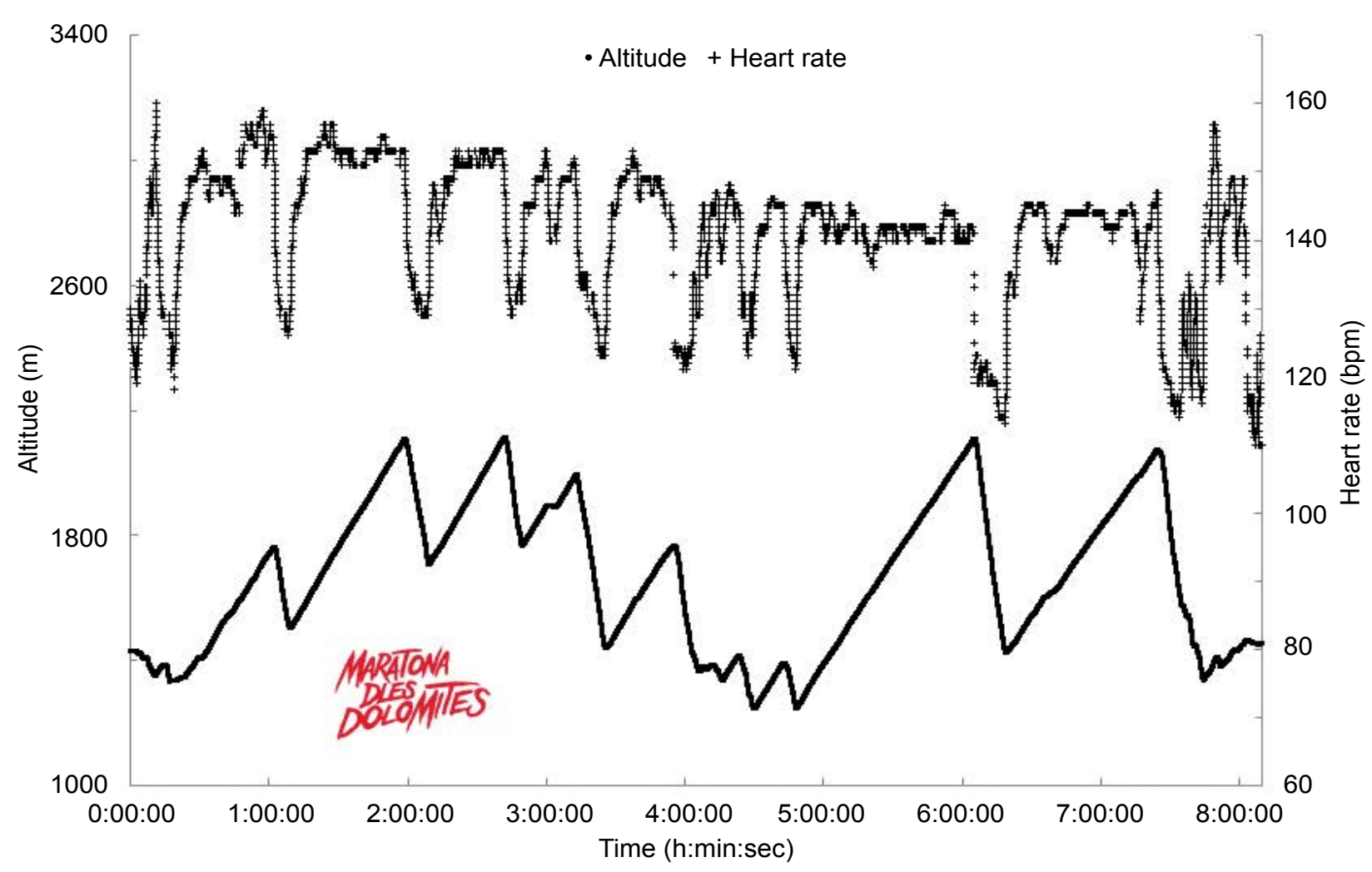

Figure 1: Altitude (continuous line) and heart rate (broken line) during the "Maratona dles Dolomites".

during the entire race were 73,141 , and $161 \mathrm{bpm}$ respectively. Lowest, mean, and highest WR values during the whole race were 54, 166, and 596 watts respectively. He remained 1 hour and 31 minutes below VT (light-to-moderate intensity, HR $115 \pm 17$ bpm); 4 hours and 6 minutes between VT and RCP (moderate-to-high intensity, HR $141 \pm 4 \mathrm{bpm}$ ); and 2 hours and 19 minutes above RCP (high-to-severe intensity, HR $151 \pm 3$ bpm). The maximal power outputs per kg of body mass for various time durations during the whole race are presented in Figure 2.

Details of the physiological variables registered during the eight mountain ascents completed during the Maratona dles Dolomites are presented in Table 2. 


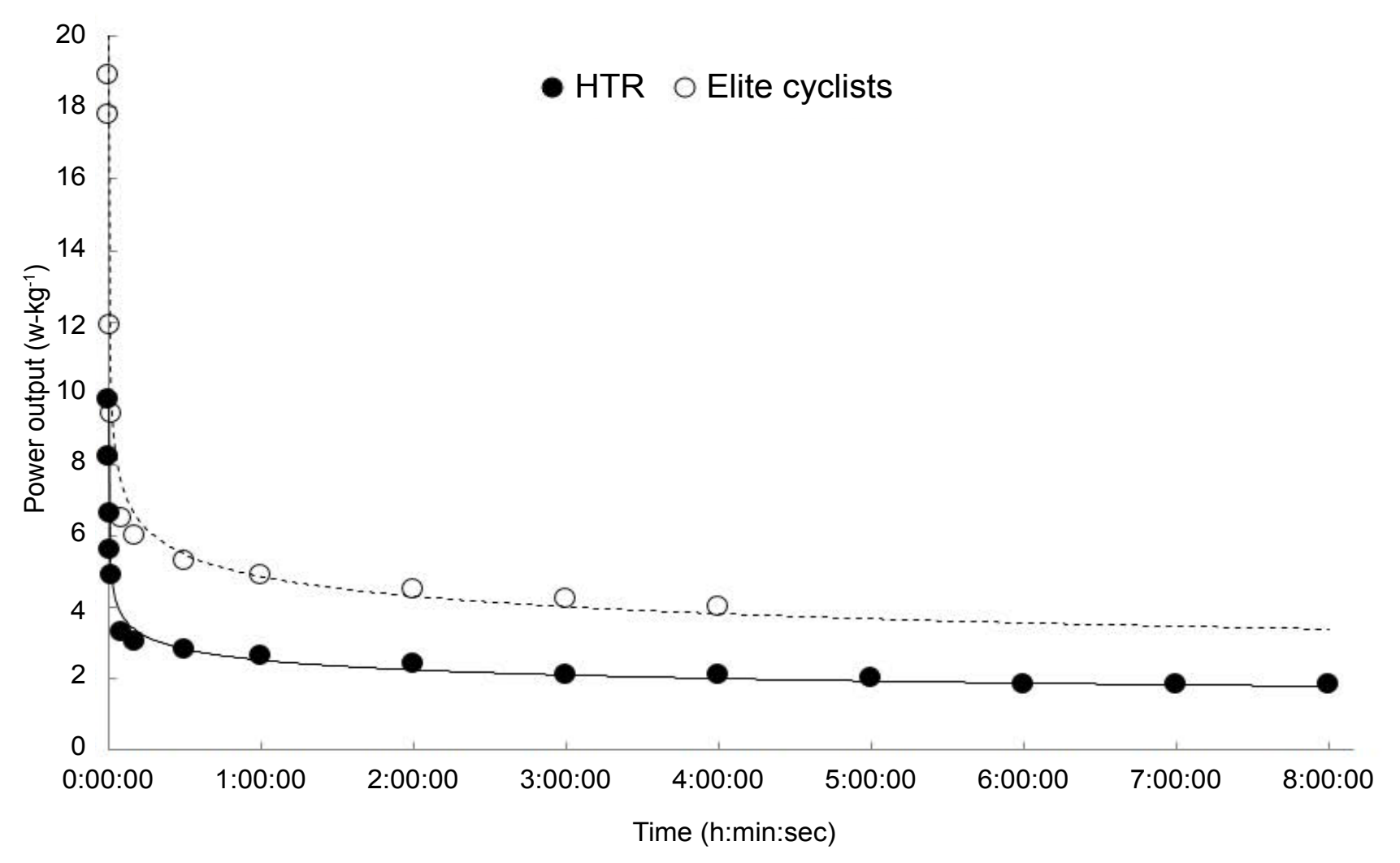

Figure 2: Power output and selected time durations through the whole race. Comparison of the profile with elite cyclists.

Table 2: Results of eight high mountain ascents in one race (Maratona dles Dolomites). n.a.: not applicable because of transient heart rate monitor dysfunction.

\begin{tabular}{|c|c|c|c|c|c|c|c|c|}
\hline Variable & Campolongo $1^{\text {st }}$ & Pordoi & Sella & Gardena & Campolongo $2^{\text {nd }}$ & Giau & Falzarego & Gatto \\
\hline Distance $(\mathrm{km})$ & 6.44 & 9.29 & 5.52 & 5.67 & 6.44 & 9.66 & 12.4 & 0.92 \\
\hline Temperature $\left({ }^{\circ} \mathrm{C}\right)$ & 15.5 & 20.7 & 18.5 & 21.4 & 30.9 & 35.8 & 35.2 & 38.6 \\
\hline Time (h:min:sec) & $0: 30: 28$ & $0: 49: 48$ & $0: 32: 56$ & $0: 23: 28$ & 0:29:39 & $1: 16: 33$ & 1:05:01 & 0:04:39 \\
\hline $\begin{array}{l}\text { Altitude (start- } \\
\text { summit, m) }\end{array}$ & $1413-1763$ & 1503-2109 & $1709-2113$ & $1770-2005$ & $1413-1763$ & $1254-2110$ & $1429-2074$ & $1340-1393$ \\
\hline $\begin{array}{l}\text { Upgrade (mean- } \\
\max , \%)\end{array}$ & $6.1-11.0$ & $6.9-10.0$ & $7.9-12.0$ & $4.3-10.0$ & $6.1-11.0$ & $9.3-15.0$ & $5.8-15.0$ & $7.2-19.0$ \\
\hline $\begin{array}{l}\text { Power output } \\
\text { (mean-max, w) }\end{array}$ & $159-259$ & $177-293$ & $176-242$ & $161-261$ & $161-254$ & $158-246$ & $149-291$ & $197-596$ \\
\hline $\begin{array}{l}\text { Cadence (mean- } \\
\text { max, rpm) }\end{array}$ & 63-112 & $62-87$ & $60-102$ & $65-106$ & $65-101$ & $52-80$ & $57-100$ & $60-79$ \\
\hline $\begin{array}{l}\text { Speed (mean- } \\
\max , \mathrm{km} / \mathrm{h} \text { ) }\end{array}$ & $12.7-34.6$ & $11.2-15.6$ & $10.6-17.2$ & $14.5-33.4$ & $13.1-25.3$ & $7.6-12.1$ & $11.5-27.0$ & $11.9-14.8$ \\
\hline \multicolumn{9}{|l|}{ Heart rate } \\
\hline $\begin{array}{l}\text { Start of the ascent } \\
\text { (bpm) }\end{array}$ & 137 & 127 & 129 & 131 & 123 & 123 & 114 & 120 \\
\hline Mean-max (bpm) & n.a.-n.a & $152-157$ & $150-153$ & $147-151$ & $146-153$ & $142-145$ & $142-145$ & $142-157$ \\
\hline $\begin{array}{l}\text { descent, 1-min } \\
\text { recovery (bpm) }\end{array}$ & 134 & 140 & 142 & 137 & 138 & n.a. & 132 & 130 \\
\hline $\begin{array}{l}\text { descent, 2-min } \\
\text { recovery (bpm) }\end{array}$ & 130 & 134 & 134 & 134 & 123 & n.a. & 123 & 118 \\
\hline
\end{tabular}

The eight-month study period was uneventful. There were no occurrences of arrhythmias, myocardial damage or ischemia.

\section{Results and Discussion}

This patient's history shows that long-term aerobic training resulted in remarkably high exercise capacity ten years after CTX. The high $\mathrm{VO}_{2}$ peak value observed (47.2 $\mathrm{mL} / \mathrm{kg} / \mathrm{min}$ ) is similar to that obtained by Haykowsky, et al. in a HTR who completed a half-ironman triathlon [13], and corresponds to excellent exercise capacity relative to agematched healthy subjects [5]. The hemoglobin values have been determined monthly during the 6 months before the cycling event, and ranged from 13.0 to $13.8 \mathrm{~g} / \mathrm{dL}$.

One contributing factor to his performance is the heart rate response to increasing exercise intensity during CPX. From rest to peak exercise we observed a 
change in heart rate of $90 \mathrm{bpm}$. The difference observed between laboratory testing and the races at higher perceived exercise intensity can be explained by the fact that racing conditions allow higher absolute and relative exercise intensities, in turn affecting the patient's metabolic requirements [14]. Higher HR max values during racing may reflect the quantity of activated muscle mass when pedaling in climbing conditions at higher absolute and relative exercise intensities [15]. Heart rate recovery showed a normal response as documented by the 23bpm decrease one minute after the end of the CPX. This response is similar to that of HTR who exhibit functional evidence of cardiac reinnervation [16]. This adaptation is likely only partial since it has been demonstrated that complete reinnervation in HTR requires 15 years [17].

Another contributing factor to the remarkable aerobic power of this individual could be a high stroke volume. We observed a normal increase in oxygen pulse in the transition from rest to exercise during CPX. The 18.8 $\mathrm{mL} /$ beat observed at peak effort is consistent with a $30 \%$ higher value than age-predicted. In contrast, patients who cannot increase their stroke volume show low oxygen pulse values. In addition, oxygen pulse promptly decreased during recovery, while it often transiently increases in patients with left ventricular dysfunction and exercise-induced myocardial ischemia. Since the oxygen pulse provides an approximation of stroke volume, these results suggest that this individual has not only normalized his stroke volume, but shows cardiac performance characteristics that mimic a healthy, highly trained person [14].

This patient's history also shows a unique and surprising aspect of exercise capacity: the ability to sustain high-intensity exercise for prolonged periods. To our knowledge, no scientific reports are available from HTR in similar events. The asymptote of the power versus time relationship observed (Figure 2 ) represents, from a mathematical standpoint, a power output theoretically sustainable for a very long or even indefinite time. The response observed in the patient $\left(0.97 . \mathrm{t}^{-0.17}, \mathrm{R}^{2}=0.99\right)$, was similar to that previously described in professional cyclists $\left(9.85 . \mathrm{t}^{-0.17}, \mathrm{R}^{2}=0.99\right)$ [8].

Aerobic endurance also depends on an individual's glycogen stores. An endurance athlete typically has about $450 \mathrm{~g}$ of glycogen at the race start. It is therefore likely that, similar to a healthy endurance athlete, this subject's muscles make greater use of fatty acids, thereby sparing glycogen. Although no biopsy reports or constant rate submaximal CPX data are available, the capacity to maintain a steady state work rate and heart rate after several hours of high intensity exercise support this concept. Moreover, this subject replenished glycogen reserves through adequate food intake before and during the race.

During the race, the patient remained -4 hours between VT and RCP, and more than 2 hours above RCP.
Although high $\mathrm{VO}_{2}$ peak values are required for success in endurance sports, other physiological variables such as the anaerobic threshold and mechanical efficiency are important $[18,19]$. The anaerobic threshold in absolute terms or as a percentage of $\mathrm{VO}_{2}$ peak is a predictor of prolonged aerobic performance (i.e., time that a given rate of ATP turnover can be maintained) [8]. This individual showed a high relative $\mathrm{RCP}$, at $86 \%$ of $\mathrm{VO}_{2}$ peak. Surprisingly, these values are similar to those observed in top-level professional road cyclists ( $85 \%)$, and close to the $\geq 90 \% \mathrm{VO}_{2}$ peak exercise intensity performed by professional cyclists [13]. The ability to maintain a steady state exercise intensity above VT may seem surprising given that the VT has been traditionally considered a limit beyond which fatigue limits effort in cardiac patients [20]. These findings provide new insights in the utilization of such variable for exercise testing and training purposes in HTR.

Another characteristic shown by this subject is his high cycling economy, i.e. the extent to which power output was generated for a given level of $\mathrm{VO}_{2}$. The $\mathrm{CPX}$ report showed a power output/oxygen uptake ratio of -80 watts per $\mathrm{L}$ of $\mathrm{O}_{2} / \mathrm{min}$, only slightly lower than the 85 watts per $\mathrm{L}$ of $\mathrm{O}_{2} / \mathrm{min}$ reported in top-10 finishers of the Tour de France [21], and higher than the average 76 watts per $L$ of $\mathrm{O}_{2} /$ min reported in elite cyclists [22]. The efficiency with which the chemical energy of ATP hydrolysis is converted to physical work depends greatly on the velocity of sarcomere and muscle fiber shortening, and type I (slow twitch) fibers have high mechanical efficiency. Although no biopsy reports are available, these results suggest that high values of mechanical efficiency, along with high \%VO${ }_{2}$ peak at RCP and HRDP reflect a high density of efficient, type I fibers in the major muscles involved in cycling [23].

In this case study, a decade of progressively longer and more intense exercise training resulted in remarkably high aerobic capacity and endurance performance after CTX, likely due to a combination of central and peripheral adaptations. These results further support the concept that in selected patients, long-term adherence to training even at high exercise intensities improves cardiovascular, respiratory, metabolic, and musculoskeletal systems following CTX.

\section{Acknowledgments}

The authors thank the patient for his involvement and high motivation during the training and racing program. The authors also thank the Italian National Transplant Centre for the scientific support.

The experiments comply with the current laws of the country in which they were performed. None of the authors declare competing financial interests. This research did not receive any specific grant from funding agencies in the public, commercial, or not-for-profit sectors. 


\section{References}

1. Taylor DO, Edwards LB, Boucek MM, Trulock EP, Aurora $P$, et al. (2007) Registry of the international society for heart and lung transplantation: twenty-fourth official adult heart transplant report-2007. J Heart Lung Transplant 26: 769781.

2. Tjang YS, van der Heijden GJ, Tenderich G, Grobbee DE, Körfer R (2008) Survival analysis in heart transplantation: results from an analysis of 1290 cases in a single center. Eur J Cardiothorac Surg 33: 856-861.

3. European Association of Cardiovascular Prevention and Rehabilitation Committee for Science Guidelines, Corrà U, Piepoli MF, Carré F, Heuschmann P, et al. (2010) Secondary prevention through cardiac rehabilitation: physical activity counselling and exercise training. Key components of the position paper from the Cardiac Rehabilitation Section of the European Association of Cardiovascular Prevention and Rehabilitation. Eur Heart J 31: 1967-1974.

4. Haykowsky M, Taylor D, Kim D, Tymchak W (2009) Exercise training improves aerobic capacity and skeletal muscle function in heart transplant recipients. Am J Transplant 9: 734-739.

5. American College of Sports Medicine (2014) Guidelines for exercise testing and prescription. (9 ${ }^{\text {th }}$ edn), PA. Lippincot Williams \& Wilkins, Philadelphia.

6. Pierce GL, Schofield RS, Casey DP, Hamlin SA, Hill JA, et al. (2008) Effects of exercise training on forearm and calf vasodilation and proinflammatory markers in recent heart transplant recipients: A pilot study. Eur J Cardiovasc Prev Rehabil 15: 10-18.

7. Braith RW, Schofield RS, Hill JA, Casey DP, Pierce GL (2008) Exercise training attenuates progressive decline in brachial artery reactivity in heart transplant recipients. J Heart Lung Transplant 27: 52-59.

8. Pinot J, Grappe F (2011) The record power profile to assess performance in elite cyclists. Int J Sports Med 32: 839-844.

9. Grazzi G, Alfieri N, Borsetto C, Casoni I, Manfredini F, et al. (1999) The power output/heart rate relationship in cycling: test standardization and repeatability. Med Sci Sports Exerc 31: 1478-1483.

10. Grazzi G, Conconi F, Myers J, Mazzoni G, Uliari S, et al. (2011) Incremental exercise using progressive versus constant pedaling rates: a study in cardiac patients. J Cardiopulm Rehabil Prev 31: 303-307.

11. Uliari S, Myers J, Bernardi E, Chiaranda G, Conconi F, et al. (2016) Oxygen uptake attenuation at ventilatory threshold in men with coronary artery disease. J Cardiopulm Rehabil Prev 36: 258-262.

12. Mezzani A, Hamm LF, Jones AM, McBride PE, Moholdt T, et al. (2012) Aerobic exercise intensity assessment and prescription in cardiac rehabilitation: a joint position statement of the European Association for Cardiovascular Prevention and Rehabilitation, the American Association of Cardiovascular and Pulmonary Rehabilitation and the Canadian Association of Cardiac Rehabilitation. J Cardiopulm Rehabil Prev 32: 327-350.

13. Haykowsky M, Tymchak W (2007) Superior athletic performance two decades after cardiac transplantation. $\mathrm{N}$ Engl J Med 356: 2007-2008.

14. Wasserman K, Hansen J, Sue D, Stringer W, Whipp B (2012) Principles of exercise testing and interpretation. ( $5^{\text {th }}$ edn), Lippincott Williams \& Wilkins, Philadelphia, USA.

15. Katch VL, McArdle WD, Katch FI (2011) Essentials of exercise physiology. (4 $4^{\text {th }}$ edn), Lippincott Williams and Wilkins, Philadelphia, 226.

16. Pokan R, Von Duvillard SP, Ludwig J, Rohrer A, Hofmann $P$, et al. (2004) Effect of high volume and -intensity endurance training in heart transplant recipients. Med Sci Sports Exerc 36: 2011-2016.

17. Bengel FM, Ueberfuhr P, Ziegler SI, Nekolla S, Reichart $B$, et al. (1999) Serial assessment of sympathetic reinnervation after orthotopic heart transplantation. A longitudinal study using PET and C-11 hydroxyephedrine. Circulation 99: 1866-1871.

18. Lucia A, Hoyos J, Chicharro JL (2001) Physiology of professional road cycling. Sports Med 31: 325-337.

19. Coyle EF (1985) Improved muscular efficiency displayed as Tour de France champion matures. J Appl Physiol 98: 2191-2196.

20. Mezzani A, Corrà U, Giordano A, Colombo S, Psaroudaki $\mathrm{M}$, et al. (2010) Upper intensity limit for prolonged aerobic exercise in chronic heart failure. Med Sci Sports Exerc 42: 633-639.

21. Lucia A, Earnest C, Arribas C (2003) The Tour de France: a physiological review. Scand J Med Sci Sports 13: 275-283.

22. Coyle EF, Feltner ME, Kautz SA, Hamilton MT, Montain SJ, et al. (1991) Physiological and biomechanical factors associated with elite endurance cycling performance. Med Sci Sports Exerc 23: 93-107.

23. Coyle EF, Sidossis LS, Horowitz JF, Beltz JD (1992) Cycling efficiency is related to the percentage of type I muscle fibers. Med Sci Sports Exerc 24: 782-788. 